\title{
Validation of an Instrument for Measuring Nutrition Literacy in Adolescents
}

\author{
M. Alejandra Amaya-Castellanos ${ }^{1}$, Luz María Gómez-Acosta ${ }^{*}$ (D), \\ Ignacio Méndez Gómez-Humaran², Teresa Shamah-Levy ${ }^{1}$ \\ ${ }^{1}$ Center for Evaluation and Surveys Research, National Institute of Public Health, Cuernavaca, Mexico \\ ${ }^{2}$ Center for Math Research, Aguascalientes, Mexico \\ Email: *ciee16@insp.mx
}

How to cite this paper: Amaya-Castellanos, M. A., Gómez-Acosta, L. M., GómezHumaran, I. M., \& Shamah-Levy, T. (2021). Validation of an Instrument for Measuring Nutrition Literacy in Adolescents. Creative Education, 12, 2146-2158.

https://doi.org/10.4236/ce.2021.129164

Received: August 18, 2021

Accepted: September 23, 2021

Published: September 26, 2021

Copyright (c) 2021 by author(s) and Scientific Research Publishing Inc. This work is licensed under the Creative Commons Attribution International License (CC BY 4.0).

http://creativecommons.org/licenses/by/4.0/

\begin{abstract}
Introduction: Nutrition literacy (NL) is a recently emerged concept related to health literacy (HL). The need for an instrument to measure NL has become increasingly urgent. Our objective is to document the validation of an instrument that measures NL in Mexican adolescents. Methods: We developed an instrument based on the definition of HL proposed by the European Health Literacy Project (HLS-EU). After adapting the HL dimensions and skills to nutrition, we built a matrix with 12 sub-dimensions and obtained 48 items for measuring the NL concept. Versions of the instrument were sequentially validated based on the judgment of experts, an evaluation with the population, a pilot trial and an analysis of the measurement model. Results: Expert judgment and evaluation corroborated the pertinence of the themes and language employed. Piloting enabled us to fine tune operational issues and establish the final version of the instrument. Lastly, an analysis of the model showed consistency and internal validity in the three model dimensions, which yielded a Cronbach alpha coefficient above 0.85. Discussion: We consider it both necessary and urgent to measure and monitor NL, contributing to the formulation of public policies grounded in evidence. Incorporating NL measurements into national surveys on health and nutrition.
\end{abstract}

\section{Keywords}

Validation Study, Nutrition Literacy Tool, Adolescents, Mexico

\section{Introduction}

Nutrition literacy (NL) is an emerging concept in the field of public health. NL and health literacy (HL) share a set of common skills (Silk et al., 2008; Velardo, 2015) considered crucial for helping individuals control their health. Besides ex- 
erting a profound influence on nutritional and dietary behaviors, HL offers a valuable tool for empowering and promoting health. As one of the major social determinants of health (Duong et al., 2017), an essential predictor of health (AMA, 1999) and a research priority in obesity, diabetes, and heart disease, it has been recognized that HL plays a vitally important role in public health (Berkman et al., 2011; Carmona, 2006).

Viewed as an area of HL that reflects the capacity to access, interpret and utilize nutritional information (Velardo, 2015), NL has been defined as "the degree to which individuals are capable of obtaining, processing and understanding basic nutritional information." (Zoellner, Connell, Bounds, Crook, \& Yadrick, 2009). Proficiency in both types of skills is essential for understanding the relationship between nutrition and health, facilitating empowerment, and restraining chronic non-communicable diseases (NCDs) (WHO, 2013). NL contributes to promote health by improving decision-making that leads to healthy eating practices. Some studies have found a positive association of healthy practices with increased NL skills (Carbone \& Zoellner, 2012; Silk et al., 2008), so they are considered an ideal result of NL (Velardo, 2015). It is also identified as a determinant factor on diet quality, especially among adolescents (Joulaei, Keshani \& Kaveh, 2018) and a predictor of adherence to healthy diet patterns (Taylor, Sullivan, Ellerbeck, Gajewski, \& Gibbs, 2019). While nutritional knowledge is fundamental in the adoption of healthy eating behaviors (Worsley, 2002), by itself it does not guarantee behavior change if it is not accompanied by other skills, fundamental for decision making, such as the search, understanding and evaluation of available nutritional information, for example. The ability to access, understand, judge, and apply such information daily is largely subject to the quality of the information provided (Sørensen et al., 2012). These competencies are manifested in the three forms of functional, interactive, and critical nutritional literacy (Guttersrud \& Petterson, 2015; Krause, Sommerhalder, Beer-Borst, \& Abel, 2018; Velardo, 2015). A strong relationship has been found between nutritional information seeking behaviors and NL and a significant association between NL and level of trust in sources of nutritional information (Zoellner et al., 2009).

In 2003, the World Health Organization (WHO) urged countries to increase the HL and NL levels in their populations, given the alarming surge in the prevalence of overweight and obesity among all age groups. The latest National Health and Nutrition Survey (ENSANUT MC 2016) (Shamah-Levy et al., 2018) in Mexico reported a $36.3 \%$ rate of the national prevalence of overweight and obesity among 12 - 19-year-old adolescents: $13.9 \%$ for obesity and $22.4 \%$ for overweight. Prevalence has been rising since 2012, particularly among female adolescents, whose rates have grown from $35.8 \%$ to $39.2 \%$; for male adolescents, estimates were $34.1 \%$ and $33.5 \%$, respectively.

In terms of health care, nutrition is considered a modifiable risk factor with individual actions. Most of the instruments developed are useful to identify levels of knowledge and understanding of health and nutrition information, focusing on the individual assessment of functional health literacy skills, but were 
not specifically designed for the nutritional field (Gibbs \& Chapman-Novakofski, 2012). Functional skills are important to the extent that they constitute the most basic degree of general literacy skills related to reading, writing, and calculus, such as 1) CARDES measure (TenHave et al., 1997) for pronunciation and word recognition, 2) Newest Vital Sign (NVS) (Weiss et al., 2005) for nutritional label literacy, 3) Nutrition Literacy Scale (NLS) (Diamond, 2007) for nutrition literacy skills and concepts, 4) Diabetes Numeracy Test (DNT) (Huizinga et al., 2008) for calculation skills. Few instruments focus on interactive or critical skills, the first involve communication and information search skills; the second-the highest level-refers to the ability to evaluate the quality of nutritional information and nutritional recommendations, and involvement in context through the understanding and influence of social determinants, respectively (Guttersrud \& Petterson, 2015; Krause et al., 2018; Velardo, 2015); 5) Critical Nutrition Literacy Scale (CNL-E) (Naigaga, Pettersen, Henjum, \& Guttersrud, 2018) to analyze nutritional information critically, 6) Nutrition Literacy Instrument for Patients with Breast Cancer (NLit-BCa) (Gibbs et al., 2016); 7) Nutrition Literacy Assessment Instrument (NLit) (Gibbs, Ellerbeck, Gajewski, Zhang, \& Sullivan, 2018) to identify the relationship between NL and quality of diet.

The purpose of our study was to document the validation process of a nutrition literacy instrument (EAN-MX-Q48) designed to measure NL in Mexican adolescents aged 15 to 19 years. Our findings intent to contribute to research by broadening the scope of studies beyond functional literacy and health care.

\section{Methods}

\subsection{Description of the EAN-MX-Q48 Measurement Instrument}

We developed the EAN-MX-Q48 questionnaire by adapting the theoretical and conceptual model of the European Health Literacy Project (HLS-EU) (Sørensen et al., 2012, 2013, 2015) to nutrition. Based on literacy in general, the HLS-EU model centers on health knowledge, and its frame is in terms of public health (Sørensen et al., 2013, 2015). It features four skills involved in the process of accessing, understanding, assessing, and applying health information in three health dimensions: 1) being ill/health care; 2) being at risk/disease prevention; and 3) being healthy/health promotion (Sørensen et al., 2012, 2013).

We adapted the four skills to the management of nutritional information and considered three nutrition dimensions: 1) attention to nutrition; 2) prevention of nutrition-related diseases; and 3) promotion of good nutrition. On this basis, we constructed a matrix with 12 sub-dimensions linked to the National Strategy for the Prevention and Control of Overweight, Obesity, and Diabetes in Mexico (Secretaría de Salud, 2013). We obtained 48 items for measuring the NL concept (Figure 1).

As in the HLS-EU, the responses in the EAN-MX-Q48 questionnaire classify 1) the degree of self-reported difficulty in each dimension and 2) the level of NL using the modifiers inadequate, problematic, sufficient, and excellent (Sørensen et al., 2013). 


\begin{tabular}{|c|c|c|c|c|}
\hline $\begin{array}{l}\text { Nutrition } \\
\text { literacy } 48\end{array}$ & $\begin{array}{l}\text { Accessing/obtaining } \\
\text { relevant information } \\
\text { on nutrition } 11\end{array}$ & $\begin{array}{l}\text { Understanding relevant } \\
\text { information on } \\
\text { nutrition } 13\end{array}$ & $\begin{array}{l}\text { Processing/valuing } \\
\text { relevant information } \\
\text { on nutrition } 15\end{array}$ & $\begin{array}{l}\text { Applying/utilizing } \\
\text { relevant } \\
\text { information on } \\
\text { nutrition } 9\end{array}$ \\
\hline $\begin{array}{l}\text { Attention to } \\
\text { nutrition } 16\end{array}$ & $\begin{array}{l}\text { (1) Capable of } \\
\text { accessing and } \\
\text { obtaining information } \\
\text { of nutritional status } \\
\text { (4 questions) }\end{array}$ & $\begin{array}{l}\text { (2) Capable of } \\
\text { understanding } \\
\text { nutritional information } \\
\text { and extracting its } \\
\text { significance } \\
\text { (5 questions) }\end{array}$ & $\begin{array}{l}\text { 3) Capable of } \\
\text { interpreting and } \\
\text { evaluating nutritional } \\
\text { information } \\
\text { (4 questions) }\end{array}$ & $\begin{array}{l}\text { 4) Capable of } \\
\text { making informed } \\
\text { decisions on } \\
\text { nutritional aspects } \\
\text { ( } 3 \text { questions) }\end{array}$ \\
\hline $\begin{array}{l}\text { Prevention of } \\
\text { nutrition-related } \\
\text { diseases } 15\end{array}$ & $\begin{array}{l}\text { (5) Capable of } \\
\text { accessing information } \\
\text { on the risk factors for } \\
\text { nutrition-related } \\
\text { diseases } \\
\text { ( } 3 \text { questions) }\end{array}$ & $\begin{array}{l}\text { (6) Capable of } \\
\text { understanding } \\
\text { information on risk } \\
\text { factors and extracting } \\
\text { its significance } \\
\text { ( } 3 \text { questions) }\end{array}$ & $\begin{array}{l}\text { 7) Capable of } \\
\text { interpreting and } \\
\text { evaluating } \\
\text { information on the } \\
\text { risk factors for } \\
\text { nutrition-related } \\
\text { diseases } \\
\text { ( } 7 \text { questions) }\end{array}$ & $\begin{array}{l}\text { (8) Capable of } \\
\text { making informed } \\
\text { decisions on the } \\
\text { risk factors for } \\
\text { nutrition-related } \\
\text { diseases } \\
\text { ( } 3 \text { questions) }\end{array}$ \\
\hline $\begin{array}{l}\text { Promotion of } \\
\text { good nutrition } \\
17\end{array}$ & $\begin{array}{l}\text { (9) Capable of } \\
\text { acquiring information, } \\
\text { without assistance, on } \\
\text { the determinants of } \\
\text { good nutrition in } \\
\text { her/his social and } \\
\text { physical environments } \\
\text { (4 questions) }\end{array}$ & $\begin{array}{l}\text { (10) Capable of } \\
\text { understanding } \\
\text { information on the } \\
\text { determinants of good } \\
\text { nutrition in her/his } \\
\text { social and physical } \\
\text { environments and of } \\
\text { extracting its } \\
\text { significance } \\
\text { ( } 5 \text { questions) }\end{array}$ & $\begin{array}{l}\text { (11) Capable of } \\
\text { interpreting and } \\
\text { evaluating } \\
\text { information on the } \\
\text { determinants of good } \\
\text { nutrition in her/his } \\
\text { social and physical } \\
\text { environments } \\
\text { ( } 4 \text { questions) }\end{array}$ & $\begin{array}{l}\text { (12) Capable of } \\
\text { making informed } \\
\text { decisions on the } \\
\text { determinants of } \\
\text { good nutrition in } \\
\text { her/his social and } \\
\text { physical } \\
\text { environments } \\
\text { ( } 3 \text { questions) }\end{array}$ \\
\hline
\end{tabular}

Figure 1. Matrix for defining nutrition literacy (NL) according to the conceptual model of the HLSEU Project (Sørensen et al., 2012) used to develop the EAN-MX-Q48 instrument.

Validating the EAN-MX-Q48 entailed four consecutive phases: 1) judgment of experts, 2) validating with population, 3) performing a pilot trial, and 4) analyzing the internal validity and consistency of the instrument.

\subsection{Phase 1. The Judgment of Experts}

Out of 53 specialists, 19 experts in public health and nutrition gave their expert judgment. Experts received a form to evaluate the instrument in terms of content, pertinence, coherence, question-wording, and importance of the themes.

\subsection{Phase 2. Validation with the Population}

For validation, we selected a sample of students of 54 adolescents 15 to 19 years old (Jiménez-Díaz, Salazar, \& Morera-Castro, 2013) from a school in Cuernavaca, Morelos, Mexico. We included the morning and afternoon shifts and the three undergraduate classes. The questionnaire validation format identified the appropriate types of questions, understandable statements, suitable language, adequate length, and accurate assessment, guaranteeing a reliable, valid, and reproducible instrument.

\subsection{Phase 3. Pilot Trial}

For the pilot trial, we selected a sample of same-age students in 8 high schools in Morelos, chosen through the website of the National System of School Information $(S N I E)$ of the Ministry of Public Education (SEP). Ten nutritionists trained and standardized in survey procedures participated in the process, monitored by 
a supervisor. During this phase, we collected information about the conditions for the data collection of the questionnaire. We also gathered sociodemographic information on the adolescents.

\subsection{Phase 4. Analysis of Internal Validity and Consistency of the Instrument}

To validate the EAN-MX-Q48 instrument, we conducted a survey of 1774 young people at 114 public schools randomly selected from the $S E P$ list for three states: Mexico, Queretaro, and Morelos. We requested informed consent and informed permission of all participants.

Measurement models were fitted for three NL dimensions through Confirmatory Factor Analysis (CFA) (Bollen, 1989; Kline, 2015), which allowed for creating measurement scales by means of latent variables generated from the items on the questionnaire. We calculated the comparative fit index (CFI) and the root mean square error of approximation (RMSEA) to measure the goodness of fit. The recommended values for a good fit are CFI $\geq 0.95$ and RMSEA $\leq 0.05$. We utilized Cronbach's alpha coefficients (Cervantes, 2005; Cronbach, 1951) for the analysis of reliability for three literacy dimensions and each sub-dimension: accessing, understanding, assessing, and applying nutritional information. We considered Cronbach's alpha coefficients greater than 0.7 as satisfactory reliability.

To characterize the participants in the sample, we calculated factor scores using the measurement models. NL indices were standardized using a 0 to 50 scale based on the formula:

$$
\text { Index }=(\text { mean }-1) *(50 / 3)
$$

For comparison purposes, NL was classified in 0 to 25 are inadequate, 26 to 33 problematic, 34 to 42 sufficient, and 43 to 50 excellent.

The Research and Ethics Committee approved this study of the National Institute of Public Health (INSP) (Project number: 1336 CI-432-2015).

\section{Results}

Figure 2 presents our findings for each phase of sequential validation:

\subsection{The Judgment of Experts}

The experts suggested improvements and found that the questionnaire is appropriate for adolescents, in line with the research objectives, and consistent with the federal government strategy for combating NCDs. We reorganized questions according to the decision matrix adjusted length and used simpler words for complex concepts.

\subsection{Validation with the Population}

We explored if the verb "judge" had negative connotations, also if the word "reliable" was clearly understood and if adolescents were familiar with the verb 


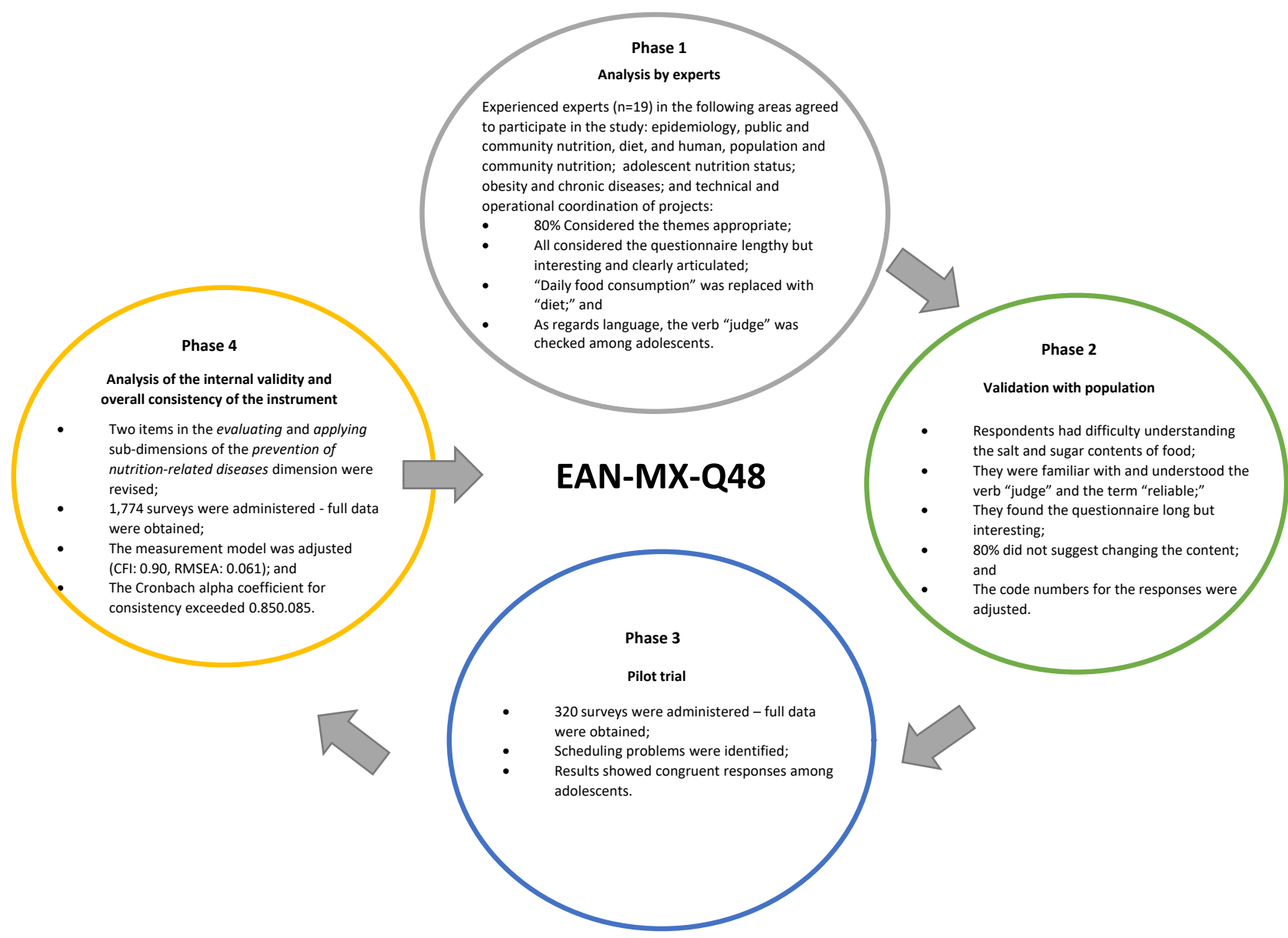

Figure 2. Sequential validation of the EAN-MX-Q48 instrument.

"judge." "Judge" meant "see which is the better alternative." Meanwhile, the word "reliable" proved challenging for the students regarding determining the degree of reliability. As a result, the verb "judge" and the term "reliable" were not replaced in the questionnaire.

Most adolescents did not suggest making changes to the questionnaire. They mentioned that they found the theme interesting enough that they had no trouble staying alert during the interviews despite its length. The validation also allowed us to correct the response code numbering.

\subsection{Pilot Trial}

After phases 1 and 2, the pilot trial allowed us to refine and correct mistakes in the data recording and the programming system. We also improved quality control procedures for interviews and information backup. The data demonstrated consistency throughout the instrument.

\subsection{Analysis of Internal Validity and Consistency of the Instrument}

Table 1 shows the main characteristics of participants. 
Table 1. Principal characteristics and overall nutrition literacy index of adolescents analyzed.

\begin{tabular}{lccc}
\hline \multicolumn{1}{c}{ Characteristics } & $\mathrm{n}$ & $\%$ \\
\hline Age in years-mean (SD) & mean (SD) & 1770 & $16.3(1.07)$ \\
Height (self-reported)-mean (SD) & & 1731 & $164.1(8.99$ \\
Weight (self-reported)-mean (SD) & & 1643 & $61.0(12.4)$
\end{tabular}

Sex

$\begin{array}{ccc}\text { Male } & 876 & 49.5 \\ \text { Female } & 894 & 50.5\end{array}$

Educational level

$\begin{array}{ccc}\text { First } & 592 & 33.5 \\ \text { Second } & 600 & 33.9 \\ \text { Third } & 575 & 32.5\end{array}$

Level of social status (self-reported)

$\begin{array}{ccc}\text { Low } & 162 & 9.1 \\ \text { Medium } & 1374 & 77.6 \\ \text { High } & 234 & 13.2\end{array}$

Level of economic status (self-reported)

$\begin{array}{ccc}\text { Low } & 878 & 53.2 \\ \text { Medium } & 604 & 36.6 \\ \text { High } & 168 & 10.2\end{array}$

Working status

$\begin{array}{ccc}\text { Works part-time } & 245 & 15.6 \\ \text { Does not work } & 1321 & 84.4 \\ & 1768 & 31.7(6.07)\end{array}$

Based on each dimension's measurement models, we rearranged two items associated with the sub-dimensions, assess, and apply, in nutrition-related disease prevention; this made more sense conceptually and provided a better indicators structure (Figure 3).

A good measurement model fit was obtained for nutritional care (Table 2), while the dimension of the promotion of good nutrition fell slightly, with a CFI of 0.90 and a RMSEA of 0.06 .

Reliability analysis showed a good consistency level, Cronbach's alpha coefficients were $(\alpha=0.86)$ for attention to nutrition, $(\alpha=0.85)$ for prevention of nutrition-related diseases, and $(\alpha=0.87)$ for promotion of good nutrition; all values were greater than $0.85(\alpha>0.85)$.

\section{Discussion}

Validation demonstrated that the EAN-MX-Q48 is a good, valid and reliable tool for measuring nutrition literacy (NL) in Mexican adolescents, which may be 


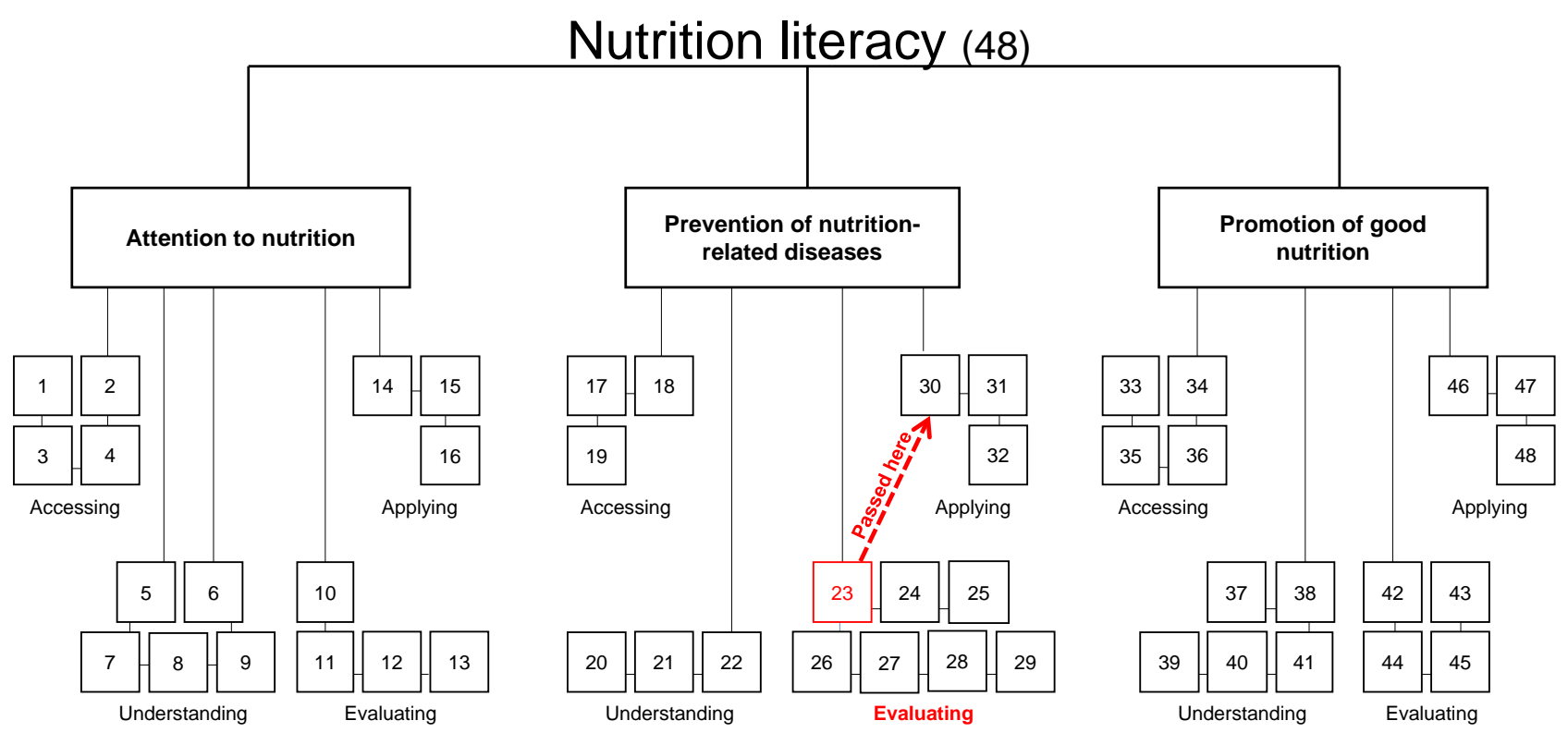

Figure 3. Sequential validation of the EAN-MX-Q48 instrument.

Table 2. Adjustments to measurement models by dimension in the EAN-MX-Q48 questionnaire.

\begin{tabular}{ccc}
\hline Dimension & CFI & RMSEA \\
\hline Attention to nutrition & 0.956 & 0.045 \\
Prevention of nutrition-related diseases & 0.94 & 0.054 \\
\hline
\end{tabular}

utilized in Latin American and other global settings with characteristics similar to those of Mexico. The instrument showed satisfactory model fit indices, validity evidence, and a high level of reliability regarding internal consistency $(\alpha>$ 0.85 ), results very similar to those for other scales. These include the NVS ( $\alpha>$ 0.76 , sensitivity of $72 \%$ ); the NLS ( $\alpha=0.84$, Pearson's construct validity correlation $=0.61)$, as well as the NLit $(\mathrm{CFI}>0.90$ and RMSEA $<0.06$, validity and reliability of $0.97, \mathrm{CI}=0.96-0.98$ ). The main differences between the EAN-MXQ48 and the other instruments lies in the number of questions (48), the duration of the implementation (approximately 20 minutes), the fact that it goes beyond functional NL (management of information and basic knowledge of diet and factors that contribute to improving or maintaining health (Velardo, 2015), the population concerned (it can be administered to a variety of population groups), and an application scope beyond primary care, as schools, universities, youth circles.

A systematic literature review by Carbone \& Zoellner (Carbone \& Zoellner, 2012) anticipated the emergence of new measurement instruments given the novelty of NL as a field of study, as well as the dearth of nutritional studies on the successful use of research instruments for nutrition (Rothman et al., 2006). A search of the literature regarding Latin America does not found an initiative similar to ours. Therefore, this work represents an advantage, as it offers a valid 
and reliable measurement instrument. Still, it also has a limitation in comparability, an issue that could be resolved by applying it in other contexts. It is noteworthy that in spite of improvement in levels of literacy (OREALC/UNESCO Santiago, 2013), the region continues to bear a heavy burden of disease (WHO, 2003, 2013) especially among children and adolescents (PAHO, 2014). This may reflect an inadequate or problematic level of NL.

The EAN-MX-Q48 instrument is helpful in incorporating a conceptual model from the field of public health (Sørensen et al., 2013) and in probing the selfperception of adolescents regarding their own NL, a different perspective in an obesogenic environment that has reached low-income households in rural areas where processed food consumption is growing (Barquera et al., 2008; Rivera, Barquera, González-Cossío, Olaiz, \& Sepúlveda, 2004; Rugani Ribeiro de Castro, 2017).

A valid and reliable measuring instrument for the Mexican context allows expanding its use in diverse contexts such as public schools with high marginalization levels, private schools, and formal and non-formal education. Available data on contrasting population groups such as students of public/private schools and universities and out-of-school youths in rural and urban areas serve to formulate future policies better.

We consider it both necessary and urgent to measure and monitor NL, contributing to the formulation of public policies grounded in evidence. Incorporating NL measurements into national surveys on health and nutrition, as Carbone y Zoellner (Carbone \& Zoellner, 2012) propose for HL, will permit periodic monitoring and thus provide robust data for government agendas that prioritize the prevention of overweight and obesity (Mussini \& Temporelli, 2013; Rugani Ribeiro de Castro, 2017; Waqa, Bell, Snowdon, \& Moodie, 2017). This is in line with policies and norms adopted locally and consistent with international and regional plans of action (Câmara dos Deputados. Senado Federal-Brasil., 2017; Rugani Ribeiro de Castro, 2017).

Just as has occurred with food labeling in the region, the Mexican Senate recently approved a General Health Law reform to include warnings about highly processed food and beverages (El Poder del Consumidor, 2019) on front labels. This policy is among other public-health measures adopted in Mexico, such as the tax on sugary drinks (IEPS) (Colchero, Popkin, Rivera, \& Ng, 2016; WHO, 2015) inspired by ample evidence from scientific studies on the benefits of such initiatives for public health.

Data derived from the EAN-MX-Q48 can contribute to expanding the evidence of scientific studies in the field and shaping food policies that take into account social, economic, and environmental determinants and are supported by other policies (Organização das Nações Unidas (ONU), 2016) destined to assist the population in their nutritional decision-making. They can also help to confront the problems of overweight and obesity among adolescents in many ways. Salient among the uses of the instrument is diagnosing levels of NL at the beginning of the school year; NL can be inserted as a compulsory component of 
curricula in elementary and middle schools; it can be integrated into teacher-training courses and serve as a framework to incorporate nutritionists into the education system to supporting nutrition education in schools (Mukamana \& Johri, 2016).

The EAN-MX-Q48 offers researchers, the scientific community, and decision-makers valuable information to design interventions with differentiated approaches. The study by Buul et al. (van Buul, Bolman, Brouns, \& Lechner, 2017) underlines the relationship between the healthy choice of food and NL level.

After the text edit has been completed, the paper is ready for the template. Duplicate the template file by using the Save As command and use the naming convention prescribed by your journal for the name of your paper. In this newly created file, highlight all the contents and import your prepared text file. You are now ready to style your paper.

\section{Conclusion}

This study is the first-ever to be based on the results of the HLS-EU-Q47 in Europe and Asia, established as a reliable, valid, and integral survey tool for HL. Using the same methodology to create an instrument for measuring NL in the Mexican adolescent population proved reliable, this tool represents an essential contribution to exploring various health care fields that need reinforcement as part of preventing disease and fostering healthy lifestyles from an early age.

\section{Conflicts of Interest}

The authors declare no conflicts of interest regarding the publication of this paper.

\section{References}

AMA (1999). Health Literacy: Report of the Council on Scientific Affairs. Ad Hoc Committee on Health Literacy for the Council on Scientific Affairs, American Medical Association. JAMA, 281, 552-557. https://doi.org/10.1001/jama.281.6.552

Barquera, S., Hernandez-Barrera, L., Tolentino, M. L., Espinosa, J., Ng, S. W., Rivera, J. A., \& Popkin, B. M. (2008). Energy Intake from Beverages Is Increasing among Mexican Adolescents and Adults. The Journal of Nutrition, 138, 2454-2461. https://doi.org/10.3945/jn.108.092163

Berkman, N. D., Sheridan, S. L., Donahue, K. E., Halpern, D. J., Viera, A., Crotty, K., Viswanathan, M. et al. (2011). Health Literacy Interventions and Outcomes: An Updated Systematic Review. Evidence Report/Technology Assessment, No. 199, 1-941.

Bollen, K. A. (1989). Confirmatory Factor Analysis. In Structural Equations with Latent Variables (pp. 226-318). John Wiley. https://doi.org/10.1002/9781118619179

Câmara dos Deputados. Senado Federal-Brasil (2017). Projeto de Lei da Câmara $N^{\circ} 102$.

Carbone, E. T., \& Zoellner, J. M. (2012). Nutrition and Health Literacy: A Systematic Review to Inform Nutrition Research and Practice. Journal of the Academy of Nutrition and Dietetics, 112, 254-265. https://doi.org/10.1016/j.jada.2011.08.042

Carmona, R. H. (2006, August). Health Literacy: A National Priority. Journal of General Internal Medicine, 21, 803. https://doi.org/10.1111/j.1525-1497.2006.00569.x

Cervantes, V. (2005). Interpretaciones del coeficiente alpha de Cronbach. Avances En 
Medición, 3, 9-28.

Colchero, M. A., Popkin, B. M., Rivera, J. A., \& Ng, S. W. (2016). Beverage Purchases from Stores in Mexico under the Excise Tax on Sugar Sweetened Beverages: Observational Study. BMJ, 352, h6704. https://doi.org/10.1136/bmj.h6704

Cronbach, L. J. (1951). Coefficient Alpha and the Internal Structure of Tests. Psychometrika, 16, 297-334. https://doi.org/10.1007/BF02310555

Diamond, J. J. (2007). Development of a Reliable and Construct Valid Measure of Nutritional Literacy in Adults. Nutrition Journal, 6, 5. https://doi.org/10.1186/1475-2891-6-5

Duong, T. V., Aringazina, A., Baisunova, G., Nurjanah, Pham, T. V., Pham, K. M., Chang, P. W. et al. (2017). Measuring Health Literacy in Asia: Validation of the HLS-EU-Q47 Survey Tool in Six Asian Countries. Journal of Epidemiology, 27, 80-86. https://doi.org/10.1016/j.je.2016.09.005

El Poder del Consumidor (2019). En jornada histórica el Senado de la República aprueba el etiquetado frontal de advertencia en la Ley General de Salud. El Pode Del Consumidor.

https://elpoderdelconsumidor.org/2019/10/en-jornada-historica-el-senado-de-la-repub lica--aprueba-el-etiquetado-frontal-de-advertencia-en-la-ley-general-de-salud

Gibbs, H., \& Chapman-Novakofski, K. (2012). A Review of Health Literacy and Its Relationship to Nutrition Education. Topics in Clinical Nutrition, 27, 325-333.

https://doi.org/10.1097/TIN.0b013e31826f8dc5

Gibbs, H. D., Ellerbeck, E. F., Befort, C., Gajewski, B., Kennett, A. R., Yu, Q., Sullivan, D. K. et al. (2016). Measuring Nutrition Literacy in Breast Cancer Patients: Development of a Novel Instrument. Journal of Cancer Education: The Official Journal of the American Association for Cancer Education, 31, 493-499.

https://doi.org/10.1007/s13187-015-0851-y

Gibbs, H. D., Ellerbeck, E. F., Gajewski, B., Zhang, C., \& Sullivan, D. K. (2018). The Nutrition Literacy Assessment Instrument Is a Valid and Reliable Measure of Nutrition Literacy in Adults with Chronic Disease. Journal of Nutrition Education and Behavior, 50, 247-257.e1. https://doi.org/10.1016/j.jneb.2017.10.008

Guttersrud, O., \& Petterson, K. S. (2015). Young Adolescents' Engagement in Dietary Behaviour-The Impact of Gender, Socio-Economic Status, Self-Efficacy and Scientific Literacy. Methodological Aspects of Constructing Measures in Nutrition Literacy Research Using the Research Model. Public Health Nutrition, 18. https://doi.org/10.1017/S1368980014003152

Huizinga, M. M., Elasy, T. A., Wallston, K. A., Cavanaugh, K., Davis, D., Gregory, R. P., Rothman, R. L. et al. (2008). Development and Validation of the Diabetes Numeracy Test (DNT). BMC Health Services Research, 8, 96.

https://doi.org/10.1186/1472-6963-8-96

Jiménez-Díaz, J., Salzar, \& Morera-Castro, M. (2013). Diseño y validación de un instrumento para la evaluación de patrones básicos de movimiento. Motricidad, 31, 87-97.

Joulaei, H., Keshani, P., \& Kaveh, M. H. (2018). Nutrition Literacy as a Determinant for Diet Quality amongst Young Adolescents: A Cross Sectional Study. Progress in Nutrition, 20.

Kline, R. B. (2015). Principles and Practice of Structural Equation Modeling. Guildford Press.

Krause, C., Sommerhalder, K., Beer-Borst, S., \& Abel, T. (2018). Just a Subtle Difference? Findings from a Systematic Review on Definitions of Nutrition Literacy and Food Literacy. Health Promotion International, 33, 378-389.

Mukamana, O., \& Johri, M. (2016). What Is Known about School-Based Interventions for 
Health Promotion and Their Impact in Developing Countries? A Scoping Review of the Literature. Health Education Research, 31, 587-602.

https://doi.org/10.1093/her/cyw040

Mussini, M., \& Temporelli, K. L. (2013). Obesidad: Un desafío para las políticas públicas. Estudios Sociales (Hermosillo, Son.), 21, 165-184.

http://www.scielo.org.mx/scielo.php?script=sci arttext\&pid=S0188-4557201300010000 $\underline{7 \& n r m=\text { iso }}$

Naigaga, D. A., Pettersen, K. S., Henjum, S. et al. (2018). Assessing Adolescents' Perceived Proficiency in Critically Evaluating Nutrition Information. International Journal of Behavioral Nutrition and Physical Activity, 15, 61. https://doi.org/10.1186/s12966-018-0690-4

OREALC/UNESCO Santiago, O. R. de E. para A. L. y el C. (2013). Situación educativa de América Latina y el Caribe: Hacia la eduación de calidad para todos al 2015. Santiago de Chile.

Organização das Nações Unidas (ONU) (2016). Roteiro para a Localização dos Objetivos de Desenvolvimento Sustentável: Implementação e Acompanhamento no nível subnacional.

PAHO (2014). Plan of Action for the Prevention of Obesity in Children and Adolescents.

Rivera, J. A., Barquera, S., González-Cossío, T., Olaiz, G., \& Sepúlveda, J. (2004). Nutrition Transition in Mexico and in Other Latin American Countries. Nutrition Reviews, 62, S149-S157. https://doi.org/10.1301/nr.2004.jul.S149-S157

Rothman, R. L., Housam, R., Weiss, H., Davis, D., Gregory, R., Gebretsadik, T., Elasy, T. A. et al. (2006). Patient Understanding of Food Labels: The Role of Literacy and Numeracy. American Journal of Preventive Medicine, 31, 391-398. https://doi.org/10.1016/j.amepre.2006.07.025

Rugani Ribeiro de Castro, I. (2017). Obesidade: Urge fazer avanÃSar políticas públicas para sua prevenÃ§̃̃o e controle. Cadernos de Saúede Pública, 33, e00100017. http://www.scielo.br/scielo.php?script=sci arttext\&pid=S0102-311X2017000700201\&n $\underline{\mathrm{rm}=\mathrm{iso}}$

https://doi.org/10.1590/0102-311x00100017

Secretaría de Salud (2013). Estrategia Nacional para la Prevención y el Control del Sobrepeso, la Obesidad y la Diabetes. Secretaría de Salud.

Shamah-Levy, T., Cuevas-Nasu, L., Gaona-Pineda, E. B., Gómez-Acosta, L. M., Morales-Rúan, M. D. C., Hernández-Ávila, M., \& Rivera-Dommarco, J. Á. (2018). Sobrepeso y obesidad en niños y adolescentes en México, actualización de la Encuesta Nacional de Salud y Nutrición de Medio Camino 2016. Salud Pública de México, 60, 244-253. https://doi.org/10.21149/8815

Silk, K. J., Sherry, J., Winn, B., Keesecker, N., Horodynski, M. A., \& Sayir, A. (2008). Increasing Nutrition Literacy: Testing the Effectiveness of Print, Web Site, and Game Modalities. Journal of Nutrition Education and Behavior, 40, 3-10.

https://doi.org/10.1016/j.jneb.2007.08.012

Sørensen, K., Pelikan, J. M., Röthlin, F., Ganahl, K., Slonska, Z., Doyle, G., Brand, H. et al. (2015). Health Literacy in Europe: Comparative Results of the European Health Literacy Survey (HLS-EU). European Journal of Public Health, 25, 1053-1058. https://doi.org/10.1093/eurpub/ckv043

Sørensen, K., Van den Broucke, S., Fullam, J., Doyle, G., Pelikan, J., Slonska, Z., European, (HLS-EU) Consortium Health Literacy Project (2012). Health Literacy and Public Health: A Systematic Review and Integration of Definitions and Models. BMC Public Health, 12, 80. https://doi.org/10.1186/1471-2458-12-80 
Sørensen, K., Van den Broucke, S., Pelikan, J. M., Fullam, J., Doyle, G., Slonska, Z., Brand, H. et al. (2013). Measuring Health Literacy in Populations: Illuminating the Design and Development Process of the European Health Literacy Survey Questionnaire (HLSEU-Q). BMC Public Health, 13, 948. https://doi.org/10.1186/1471-2458-13-948

Taylor, M. K., Sullivan, D. K., Ellerbeck, E. F., Gajewski, B. J., \& Gibbs, H. D. (2019). Nutrition Literacy Predicts Adherence to Healthy/Unhealthy Diet Patterns in Adults with a Nutrition-Related Chronic Condition. Public Health Nutrition, 22. https://doi.org/10.1017/S1368980019001289

TenHave, T. R., Van Horn, B., Kumanyika, S., Askov, E., Matthews, Y., \& AdamsCampbell, L. L. (1997). Literacy Assessment in a Cardiovascular Nutrition Education Setting. Patient Education and Counseling, 31, 139-150. https://doi.org/10.1016/S0738-3991(97)01003-3

van Buul, V. J., Bolman, C. A. W., Brouns, F. J. P. H., \& Lechner, L. (2017). Back-of-Pack Information in Substitutive Food Choices: A Process-Tracking Study in Participants Intending to Eat Healthy. Appetite, 116, 173-183.

https://doi.org/10.1016/j.appet.2017.04.036

Velardo, S. (2015). The Nuances of Health Literacy, Nutrition Literacy, and Food Literacy. Journal of Nutrition Education and Behavior, 47, 385-389.e1. https://doi.org/10.1016/j.jneb.2015.04.328

Waqa, G., Bell, C., Snowdon, W., \& Moodie, M. (2017). Factors Affecting Evidence-Use in Food Policy-Making Processes in Health and Agriculture in Fiji. BMC Public Health, 17, 51. https://doi.org/10.1186/s12889-016-3944-6

Weiss, B. D., Mays, M. Z., Martz, W., Castro, K. M., DeWalt, D. A., Pignone, M. P., Hale, F. A. et al. (2005). Quick Assessment of Literacy in Primary Care: The Newest Vital Sign. Annals of Family Medicine, 3, 514-522. https://doi.org/10.1370/afm.405

WHO (2003). Regimen alimentario, nutricion y prevencion de enfermedades cronicas: Informe de una consulta mixta FAO/OMS de expertos. https://apps.who.int/iris/handle/10665/42755

WHO (2013). Global Action Plan for the Prevention and Control of Non-Communicable Diseases 2013-2020.

WHO (2015). Taxes on Sugar-Sweetened Beverages as a Public Health Strategy: The EXperience of Mexico.

Worsley, A. (2002). Nutrition Knowledge and Food Consumption: Can Nutrition Knowledge Change Food Behaviour? Asia Pacific Journal of Clinical Nutrition, 11, S579-S585. https://doi.org/10.1046/j.1440-6047.11.supp3.7.x

Zoellner, J., Connell, C., Bounds, W., Crook, L., \& Yadrick, K. (2009). Nutrition Literacy Status and Preferred Nutrition Communication Channels among Adults in the Lower Mississippi Delta. Preventing Chronic Disease, 6, A128. 